\title{
Efek Hepatotoksisitas Tanaman Obat
}

\author{
Vally T. T. Fatti, ${ }^{1}$ Poppy M. Lintong, ${ }^{2}$ Maria K. Sambuaga ${ }^{2}$
}

\author{
${ }^{1}$ Program Studi Pendidikan Dokter Fakultas Kedokteran Universitas Sam Ratulangi, Manado, \\ Indonesia \\ ${ }^{2}$ Bagian Patologi Anatomi Fakultas Kedokteran Universitas Sam Ratulangi, Manado, Indonesia \\ Email: vallyfatti97@gmail.com
}

\begin{abstract}
The utilization of medicinal plants in Indonesia has been going on for generations even before modern medicine began to be marketed. Although its properties are widely known, but certain medicinal plants can give toxic effects to the liver. This study was aimed to re-evaluate the hepatotoxic effects of medicinal plants and changes in liver morphology. This was a literature review study using databases of Pubmed, ClinicalKey, and Google Scholar. The results obtained five medicinal plants that had hepatotoxic effects. Areca catechu showed morphological changes in the form of hemorrhagic, sinusoid dilation, lobular inflammation, lobular disarray, necrosis, interface hepatitis, microsteatosis, hepatocellular cholestasis, and steatosis. Myrmecodia pendans showed the presence of fat degeneration, necrosis, and inflammatory cell infiltration. Annona muricata indicated the presence of hepatocyte swelling. Gynura divaricata showed increases of SGOT and SGPT levels. Vernonia amygdalina Del showed the presence of cellular degeneration and necrosis of hepatocytes. In conclusion, the most diverse morphological changes of liver are caused by Areca catechu along with large dose consumption meanwhile the most minimal morphological changes of the liver are caused by Annona muricata.
\end{abstract}

Keywords: herbal medicine; hepatotoxic effect

\begin{abstract}
Abstrak: Pemanfaatan tanaman obat di Indonesia telah berlangsung selama turun-temurun bahkan sebelum obat modern mulai dipasarkan. Meskipun khasiatnya telah banyak diketahui, namun tanaman obat tertentu dapat memberikan efek toksik pada hati. Penelitian ini bertujuan untuk mengevaluasi kembali efek hepatotoksik tanaman obat dan perubahan morfologik hati. Jenis penelitian ialah literature review, menggunakan database Pubmed, ClinicalKey, dan Google Scholar. Hasil penelitian ini mendapatkan lima jenis tanaman obat yang bersifat hepatotoksik. Areca catechu menunjukkan adanya perubahan morfologik berupa perdarahan, dilatasi sinusoid, inflamasi lobular, lobular disarray, nekrosis, interface hepatitis, mikrosteatosis, kolestasis hepatoseluler, dan steatosis. Myrmecodia pendans menunjukkan adanya degenerasi lemak, nekrosis, dan infiltrasi sel radang. Annona muricata menunjukkan adanya pembengkakan hepatosit. Gynura divaricata menunjukkan adanya peningkatan kadar SGOT dan SGPT. Vernonia amygdalina Del menunjukkan adanya degenerasi dan nekrosis hepatosit. Simpulan penelitian ini ialah perubahan morfologik hati yang paling beragam disebabkan oleh Areca catechu seiring dengan besar dosis yang dikonsumsi sedangkan perubahan morfologik hati yang paling minimal disebabkan oleh Annona muricata.
\end{abstract}

Kata kunci: tanaman obat; efek hepatotoksik

\section{PENDAHULUAN}

Di Amerika Serikat, risiko hepatotoksisitas atau cedera jaringan hati akibat penggunaan produk herbal telah menjadi perhatian penting di kalangan para ilmuan.
Semua suplemen makanan yang dijual termasuk suplemen botani diatur oleh Food and Drug Administration (FDA). ${ }^{1}$ Navarro et al melakukan penelitian terhadap pasien dengan cedera hati yang dirujuk ke pusat 
The Drug-Induced Liver Injury Network (DILIN) yang memenuhi syarat pada rentang tahun 2004-2013. Tujuan penelitian tersebut untuk mempelajari hepatotoksisitas akibat pengobatan menggunakan herbal and dietary supplements (HDS). Sampel akhir terdiri dari $130(15,5 \%)$ dari total 839 subjek terdaftar yang dinilai telah mengalami cedera hati karena HDS. Hasil akhir menunjukkan adanya peningkatan cedera hati akibat HDS sebesar 7\% menjadi 20\% (p $<0,001)$ selama masa penelitian. ${ }^{2}$

Areca catechu, Myrmecodia pendans, Annona muricata, Gynura divaricata, Vernonia amygdalina Del, dan Arcangelisia flave L Merr merupakan beberapa tanaman obat yang umum digunakan di Indonesia, namun ternyata dapat menyebabkan gangguan pada organ hati bila tidak digunakan dengan dosis yang tepat. Hal ini melatarbelakangi penulis melakukan suatu penelitian dalam bentuk literature review mengenai hepatotoksisitas tanaman obat serta gambaran morfologik hati yang dapat terjadi bila mengonsumsi tanaman-tanaman obat tersebut.

\section{METODE PENELITIAN}

Penelitian ini merupakan suatu literature review. Data yang diambil merupakan data sekunder yang diperoleh dari hasil penelitian, artikel, atau jurnal ilmiah yang diterbitkan dalam jurnal nasional maupun internasional.

\section{HASIL PENELITIAN}

Pada penelitian ini didapatkan delapan literatur yang diambil menjadi data penelitian yang sesuai dengan kriteria inklusi. Delapan literatur ini membahas lima tanaman obat yang umum digunakan di Indonesia untuk pengobatan atau pun sebagai penambah stamina tubuh, namun rupanya memiliki efek hepatotoksik. Tabel 1 memperlihatkan daftar literatur yang digunakan dalam penelitian ini sedangkan Tabel 2 memuat kandungan, manfaat dan efek hepatotoksik dari masing-masing tanaman obat tersebut.

Tabel 1. Hasil pencarian literatur yang dikaji dalam penelitian

\begin{tabular}{|c|c|c|}
\hline Peneliti/Tahun & Judul & $\begin{array}{c}\text { Tanaman } \\
\text { Obat (TO) }\end{array}$ \\
\hline Rahman AO, 2018 & $\begin{array}{l}\text { Efek hepatotoksik jus pinang muda (Areca catechu) pada } \\
\text { tikus }\end{array}$ & $\begin{array}{l}\text { Areca } \\
\text { catechu }\end{array}$ \\
\hline Rahman AO, $2018^{4}$ & $\begin{array}{l}\text { Efek pemberian tunggal pinang muda dosis tinggi pada } \\
\text { hepar tikus }\end{array}$ & $\begin{array}{l}\text { Areca } \\
\text { catechu }\end{array}$ \\
\hline $\begin{array}{l}\text { Prasetyo YE et al, } \\
2018^{5}\end{array}$ & $\begin{array}{l}\text { Perubahan histopatologi hati mencit yang diberikan } \\
\text { ekstrak etanol tanaman sarang semut }\end{array}$ & $\begin{array}{l}\text { Myrmecodi } \\
\text { a pendans }\end{array}$ \\
\hline Syafitri M et al, $2017^{6}$ & $\begin{array}{l}\text { Pemberian ekstrak daun sirsak jangka panjang } \\
\text { menyebabkan cedera jaringan hati yang bersifat } \\
\text { reversibel }\end{array}$ & $\begin{array}{l}\text { Annona } \\
\text { muricata }\end{array}$ \\
\hline Sari ED et al, $2019^{7}$ & $\begin{array}{l}\text { Efek ekstrak air daun sirsak (Annona muricata L) } \\
\text { terhadap kadar SGOT dan SGPT serum serta jumlah } \\
\text { nekrosis sel hepar tikus model hiperlipidemia }\end{array}$ & $\begin{array}{l}\text { Annona } \\
\text { muricata }\end{array}$ \\
\hline $\begin{array}{l}\text { Christinia I et al, } \\
2016^{8}\end{array}$ & $\begin{array}{l}\text { Pengaruh ekstrak daun dewa (Gynura divaricata) } \\
\text { terhadap kadar SGOT dan SGPT (studi eksperimental } \\
\text { pada tikus Sprague dawley betina model kanker } \\
\text { payudara) }\end{array}$ & $\begin{array}{l}\text { Gynura } \\
\text { divaricata }\end{array}$ \\
\hline Chen J et al, $2017^{9}$ & $\begin{array}{l}\text { Detection and toxicity evaluation of pyrrolizidine } \\
\text { alkaloids in medicinal plants Gynura bicolor and Gynura } \\
\text { divaricata collected from different Chinese locations. }\end{array}$ & $\begin{array}{l}\text { Gynura } \\
\text { divaricata }\end{array}$ \\
\hline Aufia W et al, $2018^{10}$ & $\begin{array}{l}\text { Uji toksisitas sub akut infusa daun Afrika (Vernonina } \\
\text { amygdalina Del) terhadap histopatologi hati }\end{array}$ & $\begin{array}{l}\text { Vernonia } \\
\text { amygdalina } \\
\text { Del }\end{array}$ \\
\hline
\end{tabular}


42 Medical Scope Journal (MSJ), Volume 3, Nomor 1, Juli-Desember 2021, hlm. 40-46

Tabel 2. Manfaat, toksin, dan gambaran morfologik hati masing-masing tanaman obat

\begin{tabular}{|c|c|c|c|c|}
\hline $\begin{array}{c}\text { Tanaman } \\
\text { Obat }\end{array}$ & Manfaat & Toksin & Perubahan morfologik hati & Keterangan \\
\hline $\begin{array}{l}\text { Areca catechu } \\
\text { (Pinang) }\end{array}$ & $\begin{array}{l}\text { Penambah stamina } \\
\text { tubuh, anti bakteri, } \\
\text { efek hipoglikemik, } \\
\text { dan anti inflamasi }\end{array}$ & $\begin{array}{l}\text { Alkaloid } \\
\text { (Arecoline, } \\
\text { arecaidine, } \\
\text { guvacine, } \\
\text { dan } \\
\text { guvacoline) }\end{array}$ & $\begin{array}{l}\text { Perdarahan, dilatasi sinusoid, } \\
\text { inflamasi portal, inflamasi } \\
\text { lobular, lobular disarray, } \\
\text { nekrosis, interface hepatitis, } \\
\text { mikrosteatosis, kolestasis } \\
\text { hepatoseluler, dan steatosis. }\end{array}$ & - \\
\hline $\begin{array}{l}\text { Myrmecodia } \\
\text { pendans } \\
\text { (Tanaman } \\
\text { Sarang Semut) }\end{array}$ & $\begin{array}{l}\text { Antimikroba, } \\
\text { antidiabetes } \\
\text { (meningkatkan } \\
\text { sensitivitas insulin), } \\
\text { dan antikanker }\end{array}$ & - & $\begin{array}{l}\text { Degenerasi lemak, nekrosis, } \\
\text { dan infiltrasi sel radang pada } \\
\text { sel hati }\end{array}$ & - \\
\hline $\begin{array}{l}\text { Annona } \\
\text { muricata (Daun } \\
\text { sirsak) }\end{array}$ & $\begin{array}{l}\text { Menurunkan kadar } \\
\text { kolesterol darah }\end{array}$ & - & Pembengkakan sel hati & $\begin{array}{l}\text { Terdapat } \\
\text { peningkatan } \\
\text { SGOT dan } \\
\text { SGPT }\end{array}$ \\
\hline $\begin{array}{l}\text { Gynura } \\
\text { divaricate } \\
\text { (Daun Dewa) }\end{array}$ & $\begin{array}{l}\text { Mencegah } \\
\text { pembentukan radikal } \\
\text { bebas }\end{array}$ & Senyawa PA & Nekrosis sel hati & $\begin{array}{l}\text { Terdapat } \\
\text { peningkatan } \\
\text { kadar SGOT } \\
\text { dan SGPT }\end{array}$ \\
\hline $\begin{array}{l}\text { Vernonia } \\
\text { amygdalina Del } \\
\text { (Daun Afrika) }\end{array}$ & $\begin{array}{l}\text { Anti parasit, anti } \\
\text { malaria, anti helmen- } \\
\text { tik, antiviral, anti } \\
\text { kanker, anti koagu- } \\
\text { lan, antitrombotik, } \\
\text { analgesik dan anti pi- } \\
\text { retik, anti inflamasi, } \\
\text { antioksidan, anti dia- } \\
\text { betik. }\end{array}$ & - & $\begin{array}{l}\text { Degenerasi lemak } \\
\text { Nekrosis }\end{array}$ & - \\
\hline
\end{tabular}

PA; Pyrrolizidine Alkaloids, SGOT; Serum Glutamic Oxaloacetic Transaminase, SGPT; Serum Glutamic Pyruvic Transaminas

Literatur pertama ialah penelitian oleh Rahman $^{3}$ dengan memberikan jus pinang muda (Areca catechu) pada hewan coba yang dibagi dalam beberapa dosis secara bertahap yaitu: $250 \mathrm{mg} / \mathrm{kgBB}, 1.000 \mathrm{mg} /$ $\mathrm{kgBB}$, dan $10.000 \mathrm{mg} / \mathrm{kgBB}$. Hasil gambaran histopatologik jaringan hati yaitu pada dosis $10.000 \mathrm{mg} / \mathrm{kgBB}$ terdapat sebanyak $100 \%$ sampel mengalami inflamasi portal, inflamasi lobular, lobular disarray, nekrosis, interface hepatitis, perdarahan, dan dilatasi sinusoid. Kejadian mikrosteatosis hanya ditemukan pada $80 \%$ sampel. Persentase histopatologik jaringan hati pada dosis 250 $\mathrm{mg} / \mathrm{kgBB}$ dan dosis $1.000 \mathrm{mg} / \mathrm{kgBB}$ didapatkan hasil yang lebih rendah. Berdasarkan hasil analisis derajat kerusakan jaringan hati yang dihitung dari total skor histopatologik $(\mathrm{p}<0,05)$ menunjukkan bahwa semakin besar dosis jus pinang muda yang diberikan maka semakin besar pula derajat kerusakan yang ditimbulkan.

Literatur kedua ialah penelitian oleh Rahman $^{4}$ dengan menggunakan jus pinang muda namun dosis yang diberikan berbeda. Jus pinang muda dengan dosis tinggi yaitu $20.000 \mathrm{mg} / \mathrm{kgBB}$ diberikan kepada hewan coba dan diamati efek samping yang muncul. Perubahan morfologik hati yang terjadi dengan presentase hasil menunjukkan adanya inflamasi portal (66,7\%), kolestasis hepatoseluler $(33,3 \%)$, dan steatosis $(16,7 \%)$.

Literatur ketiga ialah penelitian oleh Prasetyo et al ${ }^{5}$ untuk mengetahui pengaruh ekstrak etanol Myrmecodia pendans ter- 
hadap gambaran histopatologik hati pada mencit. Pemberian ekstrak etanol Myrmecodia $p$. menunjukkan adanya perubahan gambaran histopatologik jaringan hati berupa degenerasi lemak, nekrosis, dan infiltrasi sel radang. Hasil uji KruskallWallis menunjukkan pemberian ekstrak etanol Myrmecodia $p$. berpengaruh bermakna $(\mathrm{p}<0,01)$ terhadap perubahan pada hepatosit.

Literatur keempat ialah penelitian oleh Syafitri et $\mathrm{al}^{6}$ mengenai tanaman obat Annona muricata. Ekstrak daun sirsak diberikan pada hewan coba dalam jangka waktu panjang. Perlakuan dibagi dalam empat kelompok, dengan pembagian kelompok 1 $(\mathrm{K} 1)=$ Kontrol; $\mathrm{K} 2=$ diberikan dosis 20 $\mathrm{mg} / \mathrm{kgBB} ; \mathrm{K} 3=40 \mathrm{mg} / \mathrm{kgBB}^{\prime}$ dan $\mathrm{K} 4=80$ $\mathrm{mg} / \mathrm{kgBB}$. Hasil penelitian mendapatkan bahwa pemberian ekstrak daun sirsak pada dosis bertahap menyebabkan terjadinya pembengkakan hepatosit. Hasil uji ANOVA $(\mathrm{p}<0,05)$ menunjukkan adanya perbedaan yang bermakna pada jumlah hepatosit yang membengkak. Dosis ekstrak daun sirsak yang menunjukkan pembengkakan sel hati paling bermakna terdapat pada kelompok perlakuan IV dengan dosis $80 \mathrm{mg} / \mathrm{kgBB}$.

Literatur kelima masih menggunakan tanaman obat Annona muricata untuk mengetahui kadar SGOT dan SGPT Serum serta jumlah nekrosis hepatosit. Penelitian ini dilakukan oleh Sari et $\mathrm{al}^{7}$ dengan menggunakan tikus model hiperlipidemia. Perlakuan dengan pemberian diet tinggi lemak tinggi fruktosa (DTLF) dan ekstrak air daun sirsak (EADS) pada hewan coba. Pada pengamatan histopatologik, terlihat belum banyak hepatosit yang mengalami nekrosis namun banyak yang mengalami pembengkakan sel dengan sitoplasma jernih. Pemberian daun sirsak dosis 200 $\mathrm{mg} / \mathrm{kgBB}$ dapat menurunkan kadar SGOT serum sebesar $45 \mathrm{U} / \mathrm{L}(\mathrm{p}<0,05)$.

Literatur keenam ialah penelitian oleh Christinia et $\mathrm{al}^{8}$ mengenai pengaruh ekstrak daun dewa (Gynura divaricata) terhadap kadar SGOT dan SGPT serum pada tikus Sprague Dawley betina model kanker payudara. Ekstrak daun dewa diberikan dengan dosis $750 \mathrm{mg} / \mathrm{kgBB}$ selama dua minggu kemudian diamati hasilnya. Pengaruh bermakna terdapat pada kadar SGOT dan pengaruh tidak bermakna pada kadar SGPT. Pada kelompok perlakuan terjadi peningkatan kadar SGOT yang bermakna secara statistik $(p<0,05)$ sebesar $25,35 \%$ dan peningkatan tidak bermakna terhadap kadar SGPT secara statistik ( $>0,05)$ sebesar $8,13 \%$ dibandingkan dengan kelompok kontrol positif.

Literatur ketujuh mengenai tanaman obat Gynura divaricata juga, diteliti oleh Chen et $\mathrm{al}^{9}$. Penelitian ini bertujuan untuk menilai kandungan pyrrolizidine alkaloids (PA) yang terdapat dalam Gynura sp. yang berasal dari beberapa daerah di Cina. Penelitian ini diuji pada sel HepG2 menggunakan uji Vitotox untuk skrining genotoksisitas yang selanjutnya berkorelasi dengan uji Ames. Hasil penelitian mendapatkan kandungan PA dengan konsentrasi tertinggi terdapat pada Gynura divaricate dari daerah Jiangsu.

Literatur kedelapan ialah penelitian oleh Aufia et al ${ }^{10}$ mengenai tanaman obat Vernonia amygdalina Del. Penelitian ini dilakukan untuk mengetahui keamanan penggunaan infusa daun Afrika yang dilakukan selama 28 hari. Daun Afrika dibagi dalam tiga konsentrasi yakni, konsentrasi $10 \% \mathrm{~b} / \mathrm{v}, 20 \% \mathrm{~b} / \mathrm{v}, 30 \% \mathrm{~b} / \mathrm{v}$ dan kelompok kontrol diberikan akuades $0,25 \mathrm{ml}$. Uji one way ANOVA mendapatkan hasil bermakna $(\mathrm{p}<0,05)$ yaitu terdapat perbedaan nyata antara kelompok perlakuan dengan kelompok kontrol. Cedera hepatosit meliputi degenerasi sel pada konsentrasi $10 \% \mathrm{~b} / \mathrm{v}$, $20 \% \mathrm{~b} / \mathrm{v}$, dan $30 \% \mathrm{~b} / \mathrm{v}$, sedangkan nekrosis sel Apada konsentrasi 20\% b/v dan 30\% b/v.

\section{BAHASAN}

Berdasarkan delapan literatur yang dikaji dalam penelitian ini, didapatkan lima tanaman obat yang memiliki kandungan bermanfaat bagi kesehatan namun memiliki efek hepatotoksik. Hepatotoksisitas tanaman obat dapat memberikan perubahan pada struktur morfologik hati tergantung dari jenis, dosis yang diberikan, dan hepatotoksisitas yang dimiliki tanaman obat tersebut. Perubahan morfologik hati yang didapat 
ialah pembengkakan hepatosit, degenerasi lemak, infiltrasi sel radang, perdarahan, dilatasi sinusoid, inflamasi portal, inflamasi lobular, lobular disarray, nekrosis, interface hepatitis, mikrosteatosis, kolestasis hepatoseluler, dan steatosis. Pola perubahan morfologik hepatosit yang diperoleh dalam penelitian ini yaitu: degenerasi dan akumulasi lemak intrasel, nekrosis, dan inflamasi. $^{3-10}$

Areca catechu ialah tanaman obat hepatotoksik yang memberikan perubahan morfologik hati yang lebih beragam dibandingkan dengan tanaman obat lain dalam penelitian ini. Literatur pertama dan kedua ${ }^{3,4}$ saling mendukung adanya efek hepatotoksik pada Areca catechu. Perubahan morfologik yang terjadi berupa perdarahan, mikrosteatosis yang terlihat seperti vakuola kosong dengan ukuran kecil dan multipel dalam sitoplasma hepatosit dengan nukleus tetap berada di tengah sel, dilatasi sinusoid, inflamasi portal, inflamasi lobular, lobular disarray, nekrosis, interface hepatitis, kolestasis hepatoseluler, dan steatosis. Cedera sel yang muncul mengikuti besar dosis jus pinang muda yang diberikan sehingga disimpulkan bahwa semakin besar dosis jus pinang muda yang diberikan maka semakin besar pula derajat kerusakan yang ditimbulkan.

Myrmecodia pendans dapat menyebabkan degenerasi lemak, infiltrasi sel, dan nekrosis pada gambaran morfologik hati. Penggunaan dosis $100 \mathrm{mg} / \mathrm{kgBB}$ telah menunjukkan adanya degenerasi lemak fokal (ringan) dan perubahan morfologik ini semakin meningkat pada dosis $200 \mathrm{mg} /$ $\mathrm{kgBB}$ dan $300 \mathrm{mg} / \mathrm{kgBB}$. Soeksmanto et al ${ }^{11}$ menyatakan bahwa perubahan morfologik hati muncul pada dosis $375 \mathrm{mg} / \mathrm{kgBB}$ dengan gambaran berupa degenerasi mid zonal dengan terbentuknya vakuola pada hepatosit.

Annona muricata diketahui memiliki manfaat sebagai antioksidan, antikanker, anti inflamasi, dan dapat menurunkan kadar kolesterol darah. ${ }^{12-15}$ Namun tanaman obat ini dapat bersifat hepatotoksik meskipun cedera hepatosit yang ditimbulkan tergolong paling ringan bila dibandingkan dengan tanaman obat lainnya dalam kajian penelitian ini. Penelitian oleh Syafitri et $\mathrm{al}^{6}$ dan Sari et $\mathrm{al}^{7}$ menunjukkkan adanya perubahan morfologik berupa pembengkakan sel atau degenerasi hidropik yang bersifat reversibel. Degenerasi hidropik atau pembengkakan sel menunjukkan gambaran mikroskopik berupa vakuola jernih dalam sitoplasma karena berisi air yang tidak menyerap warna ketika dilakukan pewarnaan. ${ }^{16}$ Hal ini disebabkan oleh bioaktivitas obat yang menjadi metabolit reaktif sehingga mampu berinteraksi dengan makromolekul seluler seperti lemak, protein, dan asam nukleat. Metabolit reaktif dapat mencetuskan gangguan ionik dan penyimpanan kalium intrasel yang menyebabkan terjadinya disfungi mitokondria dan gangguan produksi energi. Fungsi mitokondria yang menghilang dan berlanjut dengan terjadinya deplesi ATP berakibat pembengkakan hepatosit. ${ }^{17}$

Gynura divaricata dikenal dengan berbagai khasiat dalam penyembuhan bahkan dapat mencegah pembentukan radikal bebas oleh sel kanker. Hepatotoksisitas tanaman ini juga sudah banyak dikenal karena mengandung toksin berbahaya yaitu pyrrolizidine alkaloid (PA). Kandungan PA merupakan faktor pemicu terjadinya nekrosis. Terdapat sekitar 300 jenis PA, namun tidak semua memiliki efek hepatotoksik. Senecio merupakan salah satu jenis PA yang hepatotoksik. Mekanisme PA dalam menghambat proliferasi hepatosit dan menginduksi kematian sel ialah dengan mengurangi tingkat Bcl-x, anti-apoptotik protein, dan meningkatkan tingkat Bax, proapoptotik protein yang meningkatkan pelepasan sitokrom c dari mitokondria untuk apoptosis. Mekanisme lain yang diusulkan untuk menjelaskan PA penginduksi apoptosis terjadi dengan melibatkan pengurangan ekspresi p53, yang independen dari ekspresi Bcl. $^{18}$ Adanya kandungan PA dalam Gynura divaricata didukung oleh penelitian Chen et $\mathrm{al}^{9}$ bahwa konsentrasi PA tertinggi terdapat pada tanaman obat ini. Penelitian oleh Christinia et $\mathrm{al}^{8}$ mengambil kadar SGOT dan SGPT sebagai indikator untuk mengukur efek yang ditimbulkan 
Gynura divaricate terhadap tikus model kanker payudara. Peningkatan kadar SGOT dan SGPT dalam darah memresentasikan besar kerusakan hati yang terjadi. Kerusakan membran sel hati yang terjadi dapat diinduksi oleh toksin ataupun secara imunologik sehingga enzim SGOT dan SGPT keluar ke dalam aliran darah. Penelitian ini mendapatkan hasil sejalan dengan teori yaitu pemberian ekstrak Gynura divaricate dengan dosis 750 $\mathrm{mg} / \mathrm{kgBB}$ selama 14 hari dapat meningkatkan kadar SGOT dan SGPT pada kelompok perlakuan.

Vernonia amygdalina Del memiliki khasiat anti parasit, anti malaria, anti helmentik, anti inflamasi, dan anti oksidan. ${ }^{19,20}$ Efek hepatotoksik yang ditimbulkan yaitu degenerasi hepatosit dan nekrosis yang keduanya terdapat dalam dosis $20 \%$ b/v dan $30 \% \mathrm{~b} / \mathrm{v} .{ }^{10}$ Penelitian mengenai hepatotoksisitas Vernonia amygdalina Del masih terbilang sangat kurang dalam database yang digunakan, sehingga penulis tidak dapat membandingkan literatur tanaman obat ini dengan literatur lainnya.

\section{SIMPULAN}

Masing-masing tanaman obat memiliki manfaat dalam pengobatan, namun terdapat efek hepatotoksik yang dapat menyebabkan perubahan morfologik hati. Perubahan morfologik hati yang paling beragam didapatkan pada Areca catechu dan perubahan morfologik yang paling ringan didapatkan pada Annona muricata.

Untuk penelitian selanjutnya diharapkan agar dapat menambahkan jumlah database yang digunakan agar literatur yang didapatkan lebih beragam.

\section{Konflik Kepentingan}

Penulis menyatakan tidak terdapat konflik kepentingan dalam studi ini.

\section{DAFTAR ISI}

1. Avigan MI, Mozersky RP, Seeff LB. Scientific and regulatory perspectives in herbal and dietary supplement associated hepatotoxicity in the United States. Int J Mol Sci. 2016;17(3).
2. Davies SE, Craig C. Drug induced liver injury. Prog Pathol Vol 7. 2007;60(4):247-70.

3. Rahman AO. Efek hepatotoksik jus pinang muda (Areca catechu) pada tikus. J Kedokt Brawijaya. 2018;30(2):92.

4. Rahman AO. Efek pemberian tunggal pinang muda dosis tinggi pada hepar tikus. Jambi Med J [Internet]. 2018;6(2):1326. Available from: https://doi.org/ 10.22437/jmj.v6i2.5953

5. Prasetyo YE, Merdana IM, Kardena IM, Sudira IW. Gambaran histopatologi hepar mencit yang diberikan ekstrak etanol sarang semut. Bul Vet Udayana. 2019; (21):44.

6. Syafitri M, Tejasari M, Tresnasari C. Pemberian ekstrak daun sirsak jangka panjang menyebabkan cedera jaringan hati yang bersifat reversibel. Bandung Meeting on Global Medicine \& Helath (BAMGMH). 2017;1(22):120-4.

7. Sari ED, Falyani SA, Damayanti DS. Efek ekstrak air daun sirsak (Annona muricata . L) terhadap kadar SGOT dan SGPT serum serta jumlah nekrosis sel hepar tikus model hiperlipidemia. Jurnal Bio Komplementer Medicine. 2019; 6(3):1-8.

8. Christina I, Setyawati A, Tjahjono K. Pengaruh ekstrak daun dewa (gynura divaricata) terhadap kadar Sgot dan Sgpt (Studi eksperimental pada tikus Sprague Dawley betina model kanker payudara). Diponegoro Med J (Jurnal Kedokt Diponegoro). 2016;5(4):1013-25.

9. Chen J, Lü H, Fang LX, Li WL, Verschaeve L, Wang ZT, et al. Detection and toxicity evaluation of pyrrolizidine alkaloids in medicinal plants Gynura bicolor and Gynura divaricata collected from different chinese locations. Chem Biodivers. 2017;14(2). Doi: 10.1002/cbdv. 201600221

10. Wafa A, Surya ANM. Uji toksisitas sub akut infusa daun Afrika (Vernonina amygdalina Del.) terhadap histopatologi hati mencit (Mus musculus) galur BALB/c. Pharm J Islam Pharm. 2018;2(1):1-8.

11. Soeksmanto A, Simanjuntak P, Subroto MA. Uji toksisitas akut ekstrak air tanaman sarang semut (Myrmecodia pendans) terhadap histologi organ hati mencit. J Natur Indones. 2012;12(2):152.

12. George VC, Kumar DRN, Suresh PK, Kumar RA. Antioxidant, DNA protective 
46 Medical Scope Journal (MSJ), Volume 3, Nomor 1, Juli-Desember 2021, hlm. 40-46

efficacy and HPLC analysis of Annona muricata (soursop) extracts. J Food Sci Technol. 2015;52(4):2328-35.

13. Yuniarti L, Dewi MK, Lantika UA, Bhatara T. Potensi ekstrak air daun sirsak sebagai penurun kolesterol dan pengendali bobot badan. Acta Vet Indones. 2016; 4(2):82-7.

14. Mariam S, Wahab A, Jantan I, Haque A, Arshad L. Exploring the leaves of Annona muricata L. as a source of potential anti-inflammatory and anticancer agents. 2018;9(June):1-20.

15. Kaur V, Kumar M, Kumar A, Kaur K, Dhillon VS, Kaur S. Pharmacotherapeutic potential of phytochemicals: implications in cancer chemoprevention and future perspectives. Biomed Pharmacother [Internet]. 2018;97(October 2019):564-
86. Available from: http://dx.doi.org/ 10.1016/j.biopha.2017.10.124

16. Kumar V, Abbas AK, Aster JC. Robbins Basic Pathology (9th ed). Philadelphia: Elsevier, 2013; p. 335-6.

17. Loho IM, Hasan I. Drug-induced liver injury tantangan dalam diagnosis. Contin Med Educ. 2014;41(3):167-70.

18. Neuman MG, Cohen LB, Opris M, Nanau R, Jeong H. Hepatotoxicity of pyrrolizidine alkaloids. J Pharm Pharm Sci. 2015; 18(4):825-43.

19. Santoso S. Faktor fluktuasi glukosa darah. Conv Cent di Kota Tegal. 2011;6.

20. Tadesse A, Gebre-Hiwot A, Asres K, Djote M, Frommel D. The in vitro activity of Vernonia amygdalina on Leishmania aethiopica. Ethiop Med J. 1993;31(3): 183-9. 